\title{
The Change in Attitudes Towards Abortion in Former West and East Germany After Reunification: A Latent Class Analysis and Implications for Abortion Access
}

\author{
Der Einstellungswandel zum Schwangerschaftsabbruch in Ost- \\ und Westdeutschland nach der Wiedervereinigung: eine latente \\ Klassenanalyse und die Implikationen für den Zugang zu Abtreibung
}

\section{(ㄷ)(ㄱ) 옹 $\Theta$}

Authors

Franz Hanschmidt ${ }^{1}$, Julia Kaiser ${ }^{1}$, Holger Stepan ${ }^{2}$, Anette Kersting ${ }^{1}$

Affiliations

1 Department of Psychosomatic Medicine and Psychotherapy, University of Leipzig, Leipzig, Germany

2 Department of Obstetrics, University of Leipzig, Leipzig, Germany

\section{Key words}

abortion, stigma, public attitudes, access to abortion care, latent class analysis, differences in German health care services

\section{Schlüsselwörter}

Schwangerschaftsabbruch, Stigmatisierung, Einstellung der Bevölkerung, Zugang zum Schwangerschaftsabbruch, latente Klassenanalyse, Unterschiede in der deutschen Gesundheitsversorgung

$\begin{array}{ll}\text { received } & 29.1 .2019 \\ \text { revised } & 16.7 .2019 \\ \text { accepted } & 22.7 .2019\end{array}$

Bibliography

DOI https://doi.org/10.1055/a-0981-6286

Geburtsh Frauenheilk 2020; 80: 84-94 @ Georg Thieme Verlag KG Stuttgart · New York | ISSN 0016-5751

\section{Correspondence}

Franz Hanschmidt

Department of Psychosomatic Medicine and Psychotherapy, University of Leipzig

Semmelweisstraße 10, 04103 Leipzig, Germany

franz.hanschmidt@medizin.uni-leipzig.de

Supporting Information:

https://doi.org/10.1055/a-0981-6286

\section{ABSTRACT}

Introduction The legal status of abortion has changed in the regions of former East Germany after reunification due to the adoption of restrictive West German abortion policies. The aim of this study was to evaluate the impact on attitudes towards abortion and the associated health care implications in Western and Eastern Germany.

Materials and Methods Nationally representative data on public support for legally restricting abortion access were taken from the German General Social Survey and included the surveys 1992, 1996, 2000, 2006 and 2012 ( $N=14459)$. Two indicators of barriers to access to abortion care were calculated for each federal state, based on the number of abortion facilities and the proportion of women seeking abortion outside their state of residency. Data were analysed using latent class analysis.

Results Results suggested that abortion attitudes could be classified into three distinct subgroups: 1) support for abortion access independent of women's reason; 2) support on the basis of maternal or foetal health reasons but not for socio-economic reasons (e.g. financial restrictions); and 3) no support. The size of subgroups in favour of partial or complete restriction on abortion access increased in both regions over the study period and this trend could not be explained by changes in socio-demographic characteristics. Respondents living in a federal state with more barriers to access to abortion care were more likely to hold restrictive abortion attitudes.

Conclusion Negative attitudes towards abortion have increased in Western and Eastern Germany during the two decades following reunification and may harm women by limiting acceptability and accessibility of abortion care. Abortion policies, public discourse and provision of abortion care should be informed by international guidelines protecting women's health and rights. 


\section{ZUSAMMENFASSUNG}

Einleitung Der rechtliche Status des Schwangerschaftsabbruchs in den Regionen der früheren DDR hat sich nach der Wiedervereinigung und der Übernahme der restriktiveren westdeutschen Politik geändert. Ziel dieser Studie war es, die Auswirkungen dieser Veränderungen auf die Einstellungen zum Schwangerschaftsabbruch und die Implikationen für die damit verbundene Gesundheitsversorgung in Ost- und Westdeutschland zu untersuchen.

Material und Methoden Der Allgemeinen Bevölkerungsumfrage der Sozialwissenschaften aus den Jahren 1992, 1996, 2000, 2006 und 2012 ( $N=14459)$ wurden bundesweit repräsentative Daten über das Ausmaß der öffentlichen Unterstützung für den legalen Zugang zum Schwangerschaftsabbruch entnommen. Basierend auf der Anzahl der vorhandenen Einrichtungen, die Schwangerschaftsabbrüche vornehmen, und dem Anteil der Frauen, die für einen Schwangerschaftsabbruch in ein anderes Bundesland reisten, wurden pro Bundesland 2 Indikatoren kalkuliert, welche die Einschränkungen beim Zugang zur Versorgung bei Schwangerschaftsabbrüchen darstellen sollten. Die Daten wurden mittels der latenten Klassenanalyse analysiert.

Ergebnisse Die Ergebnisse deuten darauf hin, dass die Einstellungen zum Schwangerschaftsabbruch in 3 unterschiedliche Untergruppen unterteilt werden können: 1) Der Zugang zum Schwangerschaftsabbruch wird, ungeachtet der Gründe der betroffenen Frauen, unterstützt; 2) Der Zugang zum Schwangerschaftsabbruch wird unterstützt, wenn der Schwangerschaftsabbruch mit einem mütterlichen oder fetalen Gesundheitsrisiko begründet wird, nicht aber, wenn er aus sozioökonomischen Gründen (z.B. finanzielle Einschränkungen) durchgeführt wird; und 3) der Zugang zum Schwangerschaftsabbruch wird generell nicht unterstützt. Die Größe der jeweiligen Untergruppen, die eine teilweise oder gänzliche Einschränkung des Zugangs zum Schwangerschaftsabbruchs befürworten, ist im Laufe des untersuchten Studienzeitraums in beiden Regionen angestiegen und diese Tendenz war nicht auf Veränderungen in den soziodemografischen Merkmale zurückzuführen. Befragte, die in Bundesländern lebten, wo der Zugang zur Versorgung bei Schwangerschaftsabbrüchen mit größeren Hürden verbunden war, neigten eher zu restriktiveren Einstellungen zum Schwangerschaftsabbruch.

Schlussfolgerung Die negativen Einstellungen zum Schwangerschaftsabbruch sind in West- und Ostdeutschland in den 2 Jahrzehnten seit der Wiedervereinigung angestiegen. Das kann sich auf Frauen nachteilig auswirken, wenn die allgemeine Akzeptanz der Versorgung und der Zugang zur Versorgung bei Schwangerschaftsabbrüchen sinkt. Politische Maßnahmen, der öffentliche Diskurs und die Integration von Schwangerschaftsabbrüchen in die Gesundheitsversorgung sollten sich nach den internationalen Richtlinien zum Schutz von Frauengesundheit und Frauenrechten richten.

\section{Introduction}

In Germany, it is estimated that $8.2 \%$ of women will have an abortion, defined here as induced termination of pregnancy, once in their reproductive lifetime [1,2]. A total of 98721 women sought to terminate a pregnancy in 2016, equalling an overall rate of 5.7 abortions per 1000 women of reproductive age or 124.6 abortions per 1000 live births [3]. Hence, abortion is a common gynaecological procedure in Germany, despite relatively low abortion rates compared to other countries [4].

A woman's right to reproductive autonomy is supported by various international treaties and implies the removal of barriers that impede access to safe abortion care [5]. Approximately $45.1 \%$ of all abortions worldwide are unsafe, constituting a preventable cause of maternal mortality and morbidity [6]. While the majority of unsafe abortions occur in developing countries [6], inequities in access to abortion care remain in developed countries and include legal (e.g. conscientious objection without referral, mandatory counselling, waiting periods), socio-economic (e.g. low income) and health system barriers (e.g. lacking care, or training infrastructure) [7-10].

Indications of barriers to abortion care exist in Germany as well. Since the reunification of Germany in 1990, abortion is defined as illegal in Germany. First-trimester abortions on request are not legal but exempt from prosecution if the woman undergoes mandatory counselling and a three-day waiting period [11]. In addition to undermining coordinated policy development, training, and service delivery, the criminalization of abortion rein- forces the conception that abortion is immoral, thus perpetuating the stigma surrounding it $[12,13]$. Abortion stigma encompasses negative attributes ascribed to women seeking abortion and can also adversely affect abortion providers [12]. Stigma has been conceptualized as a driver of health outcomes at the population level and in the case of abortion, it is increasingly being recognized as a factor that negatively impacts on abortion service availability and women's pathways to care $[8,13-15]$. Women perceptions of negative judgement from others, including abortion providers, can lead to feelings of shame and the need to maintain secrecy, influencing when and where women seek abortion care $[15,16]$. Health professionals have cited perceived negative community attitudes as well as their own objection to abortion as a reason for their reluctance to provide abortion services $[8,17$, 18]. Attitudes stigmatizing abortion may thus contribute to shortages of providers of abortion care and increase the likelihood that women seeking abortion services must travel long distances in order to obtain them [8].

Public support for legal restrictions on abortion access may be regarded as potential predictor of the stigmatization of abortion. However, despite their relevance for women's care pathways, abortion attitudes at the public level have been only sparsely studied in Germany [19-21]. Cross-sectional studies have indicated that East Germans are significantly more supportive of abortion than their Western counterparts $[19,20]$. Some researchers have linked these regional differences in abortion attitudes within the German population to communist ideologies encouraging secularization and women's workforce participation in 
- Table 1 Distribution of responses to abortion attitude items.

\begin{tabular}{|c|c|c|c|c|}
\hline $\begin{array}{l}\text { It should be possible for a pregnant woman to obtain a legal abortion } \\
\text { if... }\end{array}$ & $\begin{array}{l}\text { Yes } \\
(\%[n])\end{array}$ & $\begin{array}{l}\text { No } \\
(\%[n])\end{array}$ & $\begin{array}{l}\text { Don't know } \\
(\%[n])\end{array}$ & $\begin{array}{l}\text { No response } \\
(\%[n])\end{array}$ \\
\hline ... there is a strong chance of serious defect in the baby? (fetal health) & $89.2(12903)$ & $6.6(950)$ & $3.9(557)$ & $0.3(49)$ \\
\hline ... she is married and does not want any more children? (no more children) & $50.5(7297)$ & $41.0(5928)$ & $8.1(1164)$ & $0.5(70)$ \\
\hline $\begin{array}{l}\text {... the woman's own health is seriously endangered by the pregnancy? } \\
\text { (woman's health) }\end{array}$ & $92.8(13415)$ & $3.8(547)$ & $3.1(445)$ & $0.4(52)$ \\
\hline $\begin{array}{l}\text {... the family has a very low income and cannot afford any more children? } \\
\text { (socio-economic restrictions) }\end{array}$ & $51.7(7469)$ & $39.4(5704)$ & $8.3(1203)$ & $0.6(83)$ \\
\hline ... she became pregnant as a result of rape? (rape) & $88.9(12850)$ & $6.3(914)$ & $4.3(621)$ & $0.5(74)$ \\
\hline ... she is not married and does not want to marry the man? (single woman) & $34.2(4951)$ & $56.5(8166)$ & $8.7(1255)$ & $0.6(87)$ \\
\hline
\end{tabular}

the former German Democratic Republic (GDR, now the region of Eastern Germany), which resulted in the legalisation of abortion until 12 weeks of pregnancy $[9,19]$. Regulations in the former Federal Republic of Germany (FDR, now the region of Western Germany), on the other hand, criminalized abortion and allowed it only in the case of third-party consent based on specific indications (i.e. in the case of rape, maternal or foetal health risks or difficult social circumstances) [9,22]. Previous research further found that support for abortion access for medical reasons was generally higher than for socio-economic reasons [20, 21, 23].

However, research regarding regional long-term trends in public attitudes towards abortion among West and East Germans following the German reunification in 1990 is limited. Specifically the population of Eastern Germany has seen major legal, social and political changes following the decline of communism in Central and Eastern Europe, having potentially reduced public support for abortion access. The reconciled abortion law for unified Germany from 1995 highlighted the state's moral obligation in protecting the life of the foetus and re-located abortion within the criminal code [22]. The resurgence of religious institutions and political conservatism might have further contributed to closing the gap in abortion attitudes between West and East Germany [5].

The aim of this study was to examine long-term trends in public support for the restriction on abortion access in the regions of Western and Eastern Germany. Additionally, we sought to explore the association between abortion attitudes and barriers to abortion care at the population level. Results may inform the understanding of the evolution of abortion attitudes in reunified Germany and their role for women's care pathways.

\section{Patients/Material and Methods}

\section{Data collection}

Data from the German version of the General Social Survey (Allgemeine Bevölkerungsumfrage der Sozialwissenschaften, ALLBUS) were used for the purpose of this study [24]. The ALLBUS is a repeated cross-sectional survey representative of the German general population aged 18 years or older. Independent samples are drawn randomly for each survey and data are collected in fully standardized, personal face-to-face interviews. Respondents from Eastern Germany are oversampled by design. In the period after German reunification, abortion attitudes were assessed in the surveys 1992, 1996, 2000, 2006 and 2012 (latest available survey at the time the present study was conducted). Data of these surveys was subsequently included in the analyses and constituted the overall study sample ( $N=14459)$. Methodological details on the sampling procedure and recruitment strategy are reported elsewhere [25].

\section{Measures}

Abortion attitudes were assessed with six items (response options: "yes”, “no”, “don't know”) asking respondents whether abortion should be legal given a range of different circumstances (e.g. in the case of foetal anomaly or socioeconomic restrictions) ( $\triangleright$ Table 1). The response option "don't know" was coded as missing due to relatively low endorsement rates (unweighted endorsement rate over all items and surveys: $6.1 \%$ ).

The following variables were associated with abortion attitudes in previous research and were subsequently included in the analyses: Women's participation in the workforce as an indicator of participants' gender-role attitudes, political identification, and religiosity $[19,26]$. Women's participation in the workforce was coded directly for female respondents; for male respondents, the workforce participation of their partner was coded, if applicable. Religiosity was measured by two variables: religious affiliation and frequency of church attendance. Age, gender, education and number of children currently living in the household were additionally included as socio-demographic controls.

We constructed two indicators of barriers to abortion care at the federal state ("Bundesland") level to assess associations with abortion attitudes in 2012 (i.e. the most recent ALLBUS survey). Indicator A was calculated as the ratio of abortion facilities (i.e. clinic or practice providing abortion) to women of reproductive age (i.e. 15-49 years). Indicator B was calculated as the proportion of women who had had their abortion outside their state of residency. The two indicator variables were subsequently assigned to participants according to the participant's state of residency using state identifiers as provided by the ALLBUS dataset. State-specific ratios of actual to planned gynaecological service availability were assigned in a similar manner to control for overall 
levels of gynaecological care. The spatial distribution of the female population within each state may be confounded with indicator $B$. For each state, we thus additionally calculated the proportion of women of reproductive age residing in districts at the border to another state (see Appendix A). When possible, data from 2012 matching the most recent ALLBUS survey were used. When 2012 data were not available, we chose data from the year closest to 2012. Further details on the construction of variables are described in Appendix A. Data were obtained from governmental and health insurance statistics [3, 27-30].

\section{Data analysis}

We applied latent class analysis (LCA) to account for diverging patterns of attitudes depending on women's reason for the abortion [31]. LCA assumes that relationships between observable variables can be explained by a number of underlying, unobservable latent classes, in which the observed variables are uncorrelated [32]. Individuals are probabilistically assigned to latent classes based on their responses to a set of observable variables. The probability of membership in a latent class is represented as the latent class size, while the probability of a particular observed response for an item within a class is called the item-response probability [32].

All models were estimated with the $R$ package Icca using a maximum-likelihood estimator with 500 different sets of random starting values [33]. We decided on the number of classes based on several statistical and qualitative indicators of model fit: the Bayesian Information Criterion (BIC), Akaikes Information Criterion (AIC) as well as the principle of parsimony and class interpretability. As the BIC has been found to outperform the AIC, more weight was given to the BIC during model selection (lower values indicate better fit) [34]. Classification accuracy was assessed by calculating the mean posterior probabilities of each latent class by most likely class membership [32].

Separate region models for Eastern and Western Germany were fit to identify whether abortion attitudes could be described by the same number of classes across regions. After deciding on the number of classes, two nested multiple group models were fit to the combined regional data to test for measurement invariance of item-response probabilities between regions:

1. a model in which class sizes and item-response probabilities were allowed to vary between regions and

2. a model with varying class sizes and item-response probabilities constrained to be equal.

The fit of these two nested models was compared by means of a likelihood-ratio test, inspection of the BIC values and class interpretability.

Subsequently, a multiple group model was run to obtain unadjusted estimates of class sizes grouped by time and region. To investigate whether changes in class sizes over time could be explained by regional changes in socio-demographic characteristics, the respective variables were incorporated into the multiple-group model (region as grouping variable) by means of latent multinomial logistic regression (1-step method) [35]. There was no indication of multicollinearity among the covariates (all r's $\leq|0.66|$ ).

In a next step, we aimed at assessing the association between abortion attitudes and the indicators of barriers to abortion care at state level. Therefore, latent regression models were fit to the 2012 survey data and indicator A and B were included as independent variables. Due to their high degree of urbanization and nested location within other states likely affecting health care structures, city states (i.e. Bremen, Berlin, Hamburg) as well as neighboring states (i.e. Niedersachsen, Schleswig-Holstein, Brandenburg) were excluded from the analyses. For indicator $A$, the analysis was adjusted for overall level of gynaecological care. For indicator $B$, the analysis was controlled for overall level of gynaecological care and the proportion of women residing close to the state border. Indicator $A$ and $B$ were split into three categories (low, medium and high risk for barriers to abortion care) using the 25th and 75th percentile as cut-off to establish a low- and high-risk group while maintaining sufficient statistical power. Final model parameters (itemprobabilities, class sizes, regression coefficients) were estimated using survey weights as provided by the ALLBUS dataset to account for oversampling of Eastern German respondents.

\section{Treatment of missings}

The total rate of missing values in the overall sample including the latent class indicators (i.e. abortion attitude items) and all covariates was $3 \%$. For the abortion attitude items only, the combined rate of missing values including responses that were completely missing (0.5\%) and "don't know" responses (6.1\%) was 6.5\%. Sensitivity analysis showed that respondents with missing values on any of the abortion attitude items were more likely to be older $(t=-5.365, d f=4950.9, p<0.001)$, to be female $\left(x^{2}=4.221\right.$, $\mathrm{df}=1, \quad \mathrm{p}=0.040)$, to be less educated $\left(x^{2}=61.983, \mathrm{df}=1\right.$, $p<0.001)$, to have a religious affiliation $\left(x^{2}=92.713, d f=1\right.$, $p<0.001)$, to be unemployed/have an unemployed partner $\left(x^{2}=37.732, d f=1, p<0.001\right)$ and to politically identify as rightwing $\left(x^{2}=7.176, d f=1, p=0.007\right)$. Hence, we discarded the assumption that data was missing completely at random but assumed that data was missing at random (i.e. dependent on values of observed data but independent of missing data) [36]. The software package used for the analyses (Icca) can account for missing data on the latent class indicator variables using an expectationmaximization (EM) type procedure, given that data is missing at random [33]. Missing values on the abortion attitudes items were thus retained in the fitting procedure. Missing values on covariates were imputed using the EM-algorithm provided by the $R$ package Amelia [37].

\section{Results}

\section{Participants}

A total of 14459 participants were included in the analyses (West: 9747, East: 4712). The sociodemographic profile of participants stratified by region is displayed in $>$ Table 2 .

\section{Identifying patterns of abortion attitude}

Within the Western and Eastern German subsamples, models with three latent classes showed the most favourable combination of fit statistics and interpretability: the BIC value indicated acceptable model fit and inspection of item-response probabilities suggested that the response patterns characterizing the latent 
- Table 2 Respondents' sociodemographic characteristics.

\begin{tabular}{|c|c|c|c|}
\hline & West (N = 9747) (\% [n]) & East $(N=4712)(\%[n])$ & Difference West-East \\
\hline Age & & & $X^{2}=29.374, d f=3, p<0.001^{\dagger}$ \\
\hline.$<18-34$ & $28.4(2772)^{*}$ & $24.9(1175)^{*}$ & \\
\hline - 35-49 & $27.5(2681)$ & $28.2(1327)$ & \\
\hline - 50-64 & $24.6(2398)^{*}$ & $28.0(1319)^{*}$ & \\
\hline . $>64$ & $19.3(1881)$ & $18.8(886)$ & \\
\hline - No response & $0.2(15)$ & $0.1(5)$ & \\
\hline Gender & & & $X^{2}=2.924, d f=1, p=0.087$ \\
\hline - Male & $48.9(4771)$ & $47.4(2235)$ & \\
\hline - Female & $51.1(4976)$ & $52.6(2477)$ & \\
\hline - No response & $0(0)$ & $0(0)$ & \\
\hline Education & & & $X^{2}=198.68, d f=1, p<0.001^{\dagger}$ \\
\hline - Low (<ISCED level 3) & $18.4(1797)^{*}$ & $9.5(446)^{*}$ & \\
\hline - High ( $\geq$ ISCED level 3) & $80.5(7846)^{*}$ & $90(4241)^{*}$ & \\
\hline - No response & $1.1(104)$ & $0.5(25)$ & \\
\hline Children raised at home & & & $x^{2}=40.77038, d f=3, p<0.001^{\dagger}$ \\
\hline .0 & $62.2(6061)^{*}$ & $60.5(2853)^{*}$ & \\
\hline$\cdot 1$ & $17.1(1664)^{*}$ & $20.4(963)^{*}$ & \\
\hline .2 & $14.2(1385)$ & $14.4(677)$ & \\
\hline$\cdot \geq 3$ & $5.5(536)^{*}$ & $3.8(177)^{*}$ & \\
\hline - No response & $1(101)$ & $0.9(42)$ & \\
\hline Women's employment & & & $X^{2}=12.015, d f=2, p=0.002^{\dagger}$ \\
\hline - Unemployed & $45.1(4397)^{*}$ & $43.2(2034)^{*}$ & \\
\hline - Employed & $43.3(4219)^{*}$ & $46.3(2180)^{*}$ & \\
\hline - Male, single & $11.4(1108)$ & $10.4(488)$ & \\
\hline - No response & $0.2(23)$ & $0.2(10)$ & \\
\hline Church attendance ${ }^{b}$ & & & $X^{2}=1040.37, d f=2, p<0.001^{\dagger}$ \\
\hline - Rarely or never & $57.4(5529)^{*}$ & $83.8(3950)^{*}$ & \\
\hline - Several times a year/month & $22.2(2167)^{*}$ & $9.7(456)^{*}$ & \\
\hline - More than once a week & $10.5(1023)^{*}$ & $3.0(143)^{*}$ & \\
\hline - No response & $1.1(107)$ & $0.8(36)$ & \\
\hline Political identification & & & $x^{2}=323.18, d f=2 p<0.001^{\dagger}$ \\
\hline - Left-wing & $27.7(2696)^{*}$ & $35.3(1661)^{*}$ & \\
\hline - Liberal & $44.5(4342)^{*}$ & $51.0(2403)^{*}$ & \\
\hline - Right-wing & $22.2(2165)^{*}$ & $10.5(493)^{*}$ & \\
\hline - No response & $5.6(544)$ & $3.3(155)$ & \\
\hline Religious affiliation & & & $X^{2}=4558.15, d f=3, p<0.001^{\dagger}$ \\
\hline - Protestant & $38.1(3717)^{*}$ & $24.6(1160)^{*}$ & \\
\hline - Catholic & $39.8(3876)^{*}$ & $4.2(199)^{*}$ & \\
\hline - Other & $7.2(701)^{*}$ & $2.8(131)^{*}$ & \\
\hline - None & $14.5(1412)^{*}$ & $68.1(3209)^{*}$ & \\
\hline - No response & $0.4(41)$ & $0.3(13)$ & \\
\hline Abortions outside state of residency, \% ${ }^{b}$ & $5.2(3091 / 59527)$ & $2.2(344 / 15860)$ & $z=263.27, d f=1, p<0.001^{\dagger}$ \\
\hline Women per abortion facility ${ }^{b}$ & $1427(674898 / 473)$ & $430(106965 / 249)$ & $z=264.93, d f=1, p<0.001^{\dagger}$ \\
\hline
\end{tabular}


- Table 3 Latent class item-response probabilities.

\begin{tabular}{|l|l|l|l|}
\hline Item: Support for access in case of... & Always opposed & Partial support & Always permissive \\
\hline ... fetal health risk & $0.13(0.03)$ & $0.94(0)$ & $0.99(0)$ \\
\hline ... no more children & $0.03(0.01)$ & $0.18(0.01)$ & $0.96(0)$ \\
\hline ... woman's health risk & $0.37(0.03)$ & $0.98(0)$ & $1(0)$ \\
\hline ... socio-economic restrictions & $0.02(0.01)$ & $0.2(0.01)$ & $0.96(0)$ \\
\hline ... rape & $0.19(0.03)$ & $0.94(0)$ & $1(0)$ \\
\hline ... single woman & $0.03(0.01)$ & $0.05(0)$ & $0.75(0.01)$ \\
\hline
\end{tabular}

Probability of class member endorsing response option "yes" per abortion attitude item and latent class displayed; bold numbers indicate itemresponse probabilities $>0.50$; standard error in parentheses.

classes were mutually exclusive (see Appendix B for a detailed description of the model selection process). Restricting item-response probabilities to be equal across regions resulted in a better statistical model fit (i.e. lower BIC value) and comparable interpretation of latent classes in the Eastern and Western German subsamples. Thus, we decided that three subgroups (i.e. latent classes) with mutually exclusive, but identical response patterns across regions (i.e. similar item-response probabilities) were most suitable to describe abortion attitudes in the Western and Eastern German subsamples.

The item-response probabilities of the final overall model with three classes are presented in $\triangleright$ Table 3. Class 1 was comprised of individuals with a low probability of supporting access to abortion under any of the queried circumstances. This class was labelled "always opposed". Class 2 contained individuals with a relatively high probability of supporting access to abortion only in the case of foetal anomaly, danger to the woman's health and rape. We labelled this class "partial support". Members of class 3 were characterized by a high probability of supporting access to abortion under all circumstances. This class was subsequently labelled "always permissive". Classification accuracy was considered high, because the respective mean class probabilities for the most likely class was $>0.9$ for all classes (Class 1: 0.91, Class 2: 0.93, Class 3: 0.92).

\section{Time trends in abortion attitudes}

The unadjusted class sizes per time and region are displayed in - Fig. 1 (East), > Fig. 2 (West). At baseline (i.e. 1992), the majority of East German respondents exhibited attitude patterns supporting unrestricted abortion access ("always permissive" class: $79.5 \%$ ), as opposed to more restrictive attitudes among West German respondents ("always permissive" class: $47.0 \%$ ). Regional differences in abortion attitudes diminished over time but remained until 2012. The size of classes characterized by more restrictive abortion attitudes increased in both Eastern and Western Germany (see also Appendix E).

Results of the latent multinomial logistic regression models showed that the time trend towards more restrictive abortion attitudes remained significant after controlling for changes in sociodemographic characteristics ( $\bullet$ Table 4 ). Thus, the trend towards more restrictive abortion attitudes could not be explained by sociodemographic changes within the Western and Eastern German population over time.

\section{Sociodemographic factors associated with abortion attitudes}

The pattern of associations was largely consistent between the two regions: Respondents with a religious affiliation and a higher frequency of church attendance, as well as respondents who were younger than 35 years were more likely to be a member of classes characterized by restrictive abortion attitudes, i.e. to be a member of the "always opposed" or "partial support" class. Respondents who:

1. identified as left-wing politically, were employed or had an employed partner;

2. were female; and/or

3. had a higher education were less likely to be a member of classes characterized by restrictive abortion attitudes.

Some associations were only observed among Western German respondents: Political identification as liberal was associated with lower and having more children with a higher likelihood of membership in classes characterized by restrictive abortion attitudes.

\section{Abortion attitudes and barriers to abortion care}

Results suggested a link between state-level barriers to abortion care and abortion attitudes. Respondents who lived in a state with 1. relatively few abortion facilities per women and

2. a relatively high proportion of women seeking out-of-state abortions

were more likely to be members of classes characterized by restrictive abortion attitudes (see Appendix F).

\section{Discussion}

In the current study, we observed that abortion attitudes in the German population could be classified into three distinct subgroups, characterized by support for unrestricted legal access to abortion (i.e. for both medical and socio-economic reasons), support only in the case of or maternal or foetal health risks and in the case of rape, or complete opposition to abortion access. Abortion attitudes were less restrictive in Eastern than in Western Germany throughout the study period, suggesting the lasting influence of secularization as well as policies supporting gender equality and abortion access in the former GDR. However, results also showed that public support for the restriction of abortion access increased 


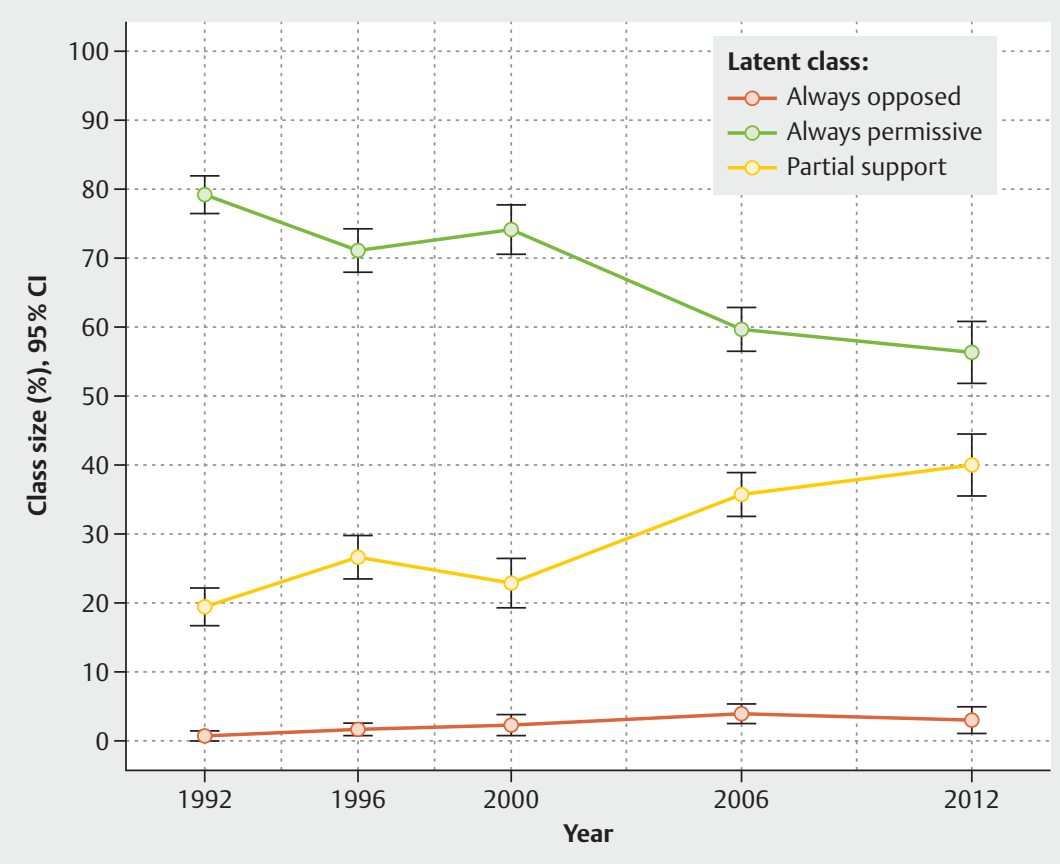

Note: $\mathrm{Y}$-axis indicates proportion of sample with respective latent class membership in given year, not adjusted for covariates.

- Fig. 1 Time trends in abortion attitudes for Eastern Germany by latent classes.

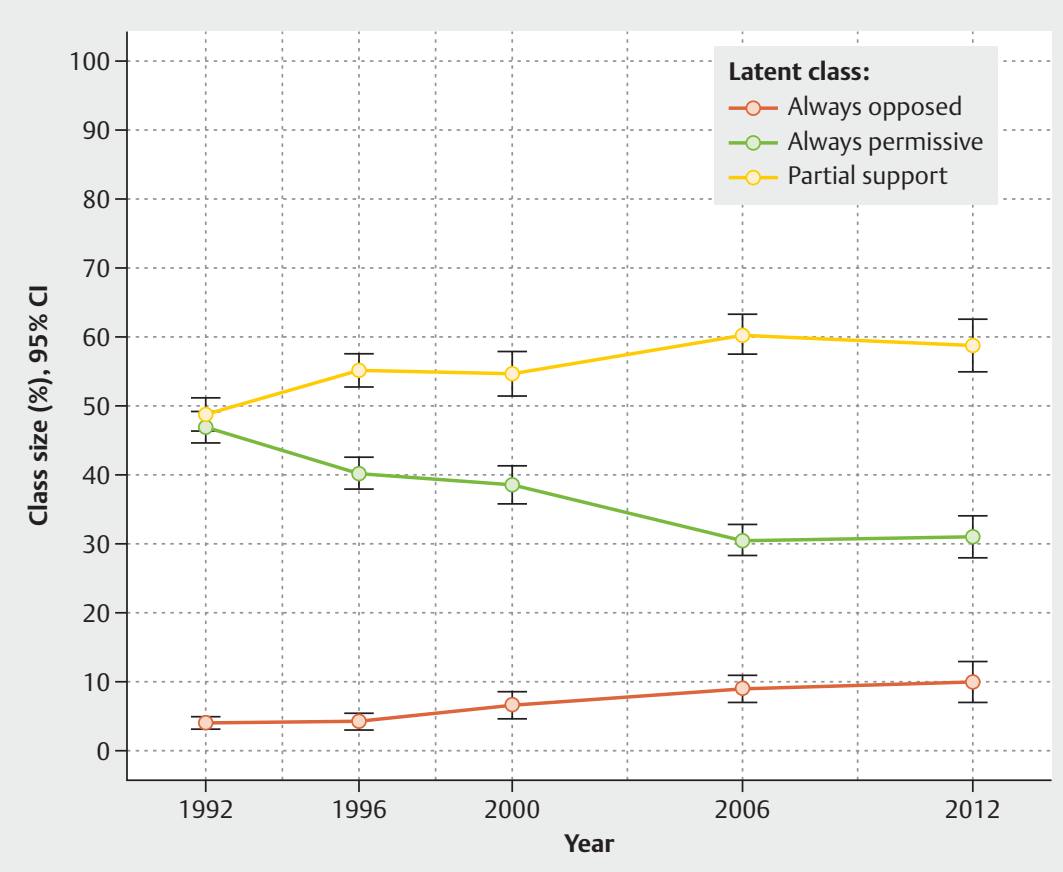

Note: $\mathrm{Y}$-axis indicates proportion of sample with respective latent class membership in given year, not adjusted for covariates.

- Fig. 2 Time trends in abortion attitudes for Western Germany by latent classes. 
- Table 4 Associations with latent class membership.

\begin{tabular}{|c|c|c|c|c|}
\hline & \multicolumn{2}{|l|}{ West } & \multicolumn{2}{|l|}{ East } \\
\hline & $\begin{array}{l}\text { Always opposed } \\
\text { (OR, } 95 \% \mathrm{Cl} \text { ) }\end{array}$ & $\begin{array}{l}\text { Partial support } \\
\text { (OR, } 95 \% \mathrm{Cl})\end{array}$ & $\begin{array}{l}\text { Always opposed } \\
\text { (OR, } 95 \% \mathrm{Cl} \text { ) }\end{array}$ & $\begin{array}{l}\text { Partial support } \\
\text { (OR, } 95 \% \mathrm{Cl})\end{array}$ \\
\hline Survey period/year ${ }^{\mathrm{a}}$ & $1.91(1.71-2.13)^{*}$ & $1.33(1.26-1.41)^{*}$ & $1.9(1.51-2.4)^{*}$ & $1.44(1.34-1.56)^{*}$ \\
\hline Gender, female & $0.99(0.78-1.27)$ & $0.86(0.77-0.95)^{*}$ & $1.06(0.63-1.78)$ & $0.81(0.69-0.96)^{*}$ \\
\hline Education, high ( $\geq$ ISCED level 3) & $0.55(0.42-0.71)^{*}$ & $0.75(0.65-0.87)^{*}$ & $0.49(0.25-0.96)^{*}$ & $0.76(0.58-0.99)^{*}$ \\
\hline \multicolumn{5}{|l|}{ Age } \\
\hline - $<35$ & $1.25(0.9-1.74)$ & $1.32(1.15-1.51)^{*}$ & $1.51(0.74-3.08)$ & $1.43(1.16-1.76)^{*}$ \\
\hline - 35-49 & Ref & Ref & Ref & Ref \\
\hline . $50-64$ & $1.05(0.76-1.46)$ & $1.09(0.94-1.27)$ & $1.03(0.47-2.27)$ & $0.82(0.65-1.04)$ \\
\hline.$>64$ & $1.33(0.9-1.97)$ & $1.22(1.01-1.47)$ & $0.91(0.35-2.35)$ & $1.13(0.85-1.51)$ \\
\hline No. of children & $1.24(1.1-1.4)^{*}$ & $1.04(0.98-1.1)$ & $1.16(0.8-1.69)$ & $1.04(0.94-1.15)$ \\
\hline \multicolumn{5}{|l|}{ Women's employment } \\
\hline - Unemployed & Ref & Ref & Ref & Ref \\
\hline - Employed & $0.62(0.48-0.8)^{*}$ & $0.86(0.76-0.96)^{*}$ & $0.49(0.27-0.89)^{*}$ & $0.67(0.55-0.81)^{*}$ \\
\hline - Male, single & $1.45(0.97-2.16)$ & $0.92(0.76-1.12)$ & $1.43(0.61-3.38)$ & $0.81(0.6-1.09)$ \\
\hline \multicolumn{5}{|l|}{ Political identification } \\
\hline - Right & Ref & Ref & Ref & Ref \\
\hline - Liberal & $0.56(0.44-0.72)^{*}$ & $0.84(0.74-0.95)^{*}$ & $0.77(0.39-1.51)$ & $0.94(0.74-1.19)$ \\
\hline - Left & $0.5(0.37-0.66)^{*}$ & $0.59(0.51-0.68)^{*}$ & $0.48(0.23-1.01)$ & $0.62(0.48-0.8)^{*}$ \\
\hline \multicolumn{5}{|l|}{ Religious affiliation } \\
\hline - None & Ref & Ref & Ref & Ref \\
\hline - Catholic & $1.95(1.24-3.07)^{*}$ & $1.83(1.57-2.13)^{*}$ & $4.76(1.93-1.73)^{*}$ & $2.21(1.54-3.17)^{*}$ \\
\hline - Protestant & $0.96(0.6-1.52)$ & $1.45(1.25-1.67)^{*}$ & $2.59(1.42-4.72)^{*}$ & $1.37(1.13-1.67)^{*}$ \\
\hline - Other & $6.77(4.08-11.24)^{*}$ & $2.09(1.61-2.71)^{*}$ & $14.33(6.06-33.89)^{*}$ & $2.04(1.25-3.34)^{*}$ \\
\hline Frequency of church attendance ${ }^{b}$ & $4.41(3.71-5.24)^{*}$ & $1.74(1.59-1.9)^{*}$ & $3.23(2.16-4.84)^{*}$ & $2.07(1.72-2.5)^{*}$ \\
\hline \multicolumn{5}{|c|}{$\begin{array}{l}\text { Results of latent multinomial regression model showing likelihood of class membership over time, controlling for sociodemographic characteristics, with } \\
\text { "always permissive" as reference class; OR: Odds ratio; } 95 \% \mathrm{Cl}: 95 \% \text { confidence interval; ISCED: International Standard Classification of Education; } \\
\text { a variable was standardized: } 1 \text { unit = } 1 \text { standard deviation }=6.71 \text { years; } \text { b higher values indicate more frequent church attendance; * } 95 \% \mathrm{Cl} \text { did not contain } 1 \\
\text { and multivariate Wald-Test of significance of predictor } p<0.05(\mathrm{df}=2) \text {. }\end{array}$} \\
\hline
\end{tabular}

between 1992 and 2012 in both regions. The population in federal states with relatively limited availability of abortion facilities and a relatively high proportion of out-of-state abortions was characterized by more restrictive abortion attitudes, indicating that social norms may play a role in determining the accessibility of abortion care.

The reconciled abortion law for reunified Germany largely adopted West German regulations, changing the legal status of abortion from a woman's right to a criminal offense in Eastern Germany, with few exceptions to liability [38]. Additional barriers to accessing abortion care for eligible women were implemented, with the rationale of protecting "unborn life" (e.g. mandatory waiting periods and counselling, conscientious objection without referral and restrictions on provision of abortion information) $[9,11,38]$. However, there is no evidence that restricting access to abortion care is a suitable means to protecting foetal life by reducing the number of abortion. Abortion rates are not higher in countries with more liberal abortion laws [39]. Several European countries have removed restrictions on access to abortion care in recent years with- out notable changes in abortion rates (e.g. France, Switzerland) $[40,41]$. Restricting abortion access, on the other hand, can harm women's health by leading to delays in the provision of care, compelling women to seek unsafe abortions outside the formal healthcare sector or causing long-lasting economic problems [6, 42, 43].

International guidelines (e.g. World Health Organization [WHO]) thus recommend that "laws and policies on abortion should protect women's health and their human rights" and that "regulatory, policy and programmatic barriers that hinder access to and timely provision of safe abortion care should be removed" (WHO) $[44,45]$. The findings of this study are concerning, as they suggest that growing proportions of the German population support policies jeopardizing women's health and right to reproductive autonomy. Moreover, the widespread divide between "legitimate" reasons for abortion justifying access (e.g. maternal health risks) and "illegitimate" abortion reasons (e.g. socio-economic restrictions) points to misperceptions of the interrelated and complex circumstances underlying women's abortion decisions in practice $[2,46]$. 
The observed trend in abortion attitudes could not be explained by changes in socio-demographic characteristics, but several other explanations might apply. Attitudes in more liberal legal settings have generally been found to be more favourable toward abortion [47]. In Eastern Germany, public perceptions of abortion as illegitimate thus may have been exacerbated by the introduction of a more restrictive abortion law after Germany's reunification. Negative abortion attitudes have also increased in the Western German population, which has experienced relatively small changes in abortion legislation after reunification. However, controversial societal debates surrounding the ethics of later abortion and preimplantation genetic diagnosis with regard to the status of the foetus have emerged during the study period $[38,48]$. It has been argued that the increasing emphasis on foetal "patienthood" as well as portrayal of reproduction as a largely controllable behavior in public health debates reinforce the stigma attached to abortions $[5,49,50]$. Furthermore, the resurgence of nationalist and religious "moral regimes" in the context of declining fertility rates and migration have recently fuelled anti-reproductive rights discourses in Europe, potentially affecting abortion attitudes in Germany [5].

The changing attitudes towards abortion may have adverse implication for women's abortion care pathways in Germany. Respondents living in a setting with limited availability of abortion care were more likely to hold restrictive abortion attitudes. Our correlation study design, however, did not allow for causal inference and interpretation of the findings was further hindered by the restricted validity of our indicators of abortion access. We were not able to directly assess the reasons for which women travelled outside their state of residency to obtain an abortion (e.g. limited abortion service availability or acceptability) and data on abortion facilities and abortion attitudes were not available for the same period as data on abortion attitudes. Although the association between negative abortion attitudes and increased barriers to abortion access was confirmed by both indicators, results need to be corroborated by future studies.

Several mechanisms explaining our findings are conceivable. Worries about negative judgement may deter medical professionals from providing abortion services in settings with high-levels of abortion stigma [17]. In support of this assumption, reports by the German Medical Association (Bundesärztekammer) have linked substantial declines in the number of abortion providers in Germany to the increasing harassment of abortion providers by pro-life activists [51,52]. Medical professionals themselves may be more likely to hold negative attitudes towards abortion in settings where abortion stigma is prevalent, interfering with their ability to provide abortion services or non-judgemental care [8, 18]. Opposition to abortion among medical professionals may be reinforced by legal sanctions against abortion providers as well as the lack of guidelines on abortion training and provision which impede normalization of abortion within the medical sector [53].

Limited abortion service availability or worries about judgement may require women to travel longer distances to access abortion services, increasing financial, physical and emotional strains especially for low-income women. Adding to the burden of finding an abortion provider, women may feel the need to keep their abortion a secret in order to avoid stigmatization, which can deprive them of their social support network [54]. However, it is unclear how support for restricting abortion access translates into stigmatization of women who have abortions or abortion providers. Using valid measures to assess women's and providers perception of abortion stigma in conjunction with public attitudes stigmatizing abortion may help to delineate the relationship between manifestations of abortion stigma at the public and individual level.

\section{Limitations}

In addition to the limitations mentioned above, this study has several shortcomings. Data on abortion attitudes were only available up to the year 2012 and may thus not reflect current attitudes in the German population. The outcome measure used in this study was limited to attitudes towards legal abortion access as other measures of abortion stigma (e.g. negative stereotyping of women or abortion providers) were not assessed in the ALLBUS survey. The circumstances queried by the abortion attitudes items did not constitute an exhaustive list of women's reasons for abortion. Thus, attitude patterns identified in this study might not capture the full range of attitude structures in the population. The same set of abortion attitude items were analysed in each year. While this allowed for comparisons across time, the items might not have adequately captured time-varying socio-cultural norms regarding reproductive decision-making and family forms. Respondents with missing data on the abortion attitude items were more likely to be older, female, less educated, to have a religious affiliation, to be unemployed/have an unemployed partner and to politically identify as right-wing. The majority of these factors were associated with more restrictive abortion attitudes, potentially leading to an underestimation of restrictive abortion attitudes in our sample. However, the overall rate of missing data was relatively small (abortion attitudes items only: 6.5\%, overall including all covariates: $3 \%$ ) and statistical methods were applied to account for missing data, reducing risk of bias resulting from missing data.

Respondents were classified as Eastern/Western German according to the region where the data was collected (i.e. region of interview), not where they were born or spent their youth (region of origin). Thus, some participants with Eastern German origin might have been misclassified as Western German and vice versa due to domestic migration occurring after the German reunification, potentially biasing regional results. Using information provided by the ALLBUS dataset, we conducted a sensitivity analysis which excluded respondents for which region of interview did not match region of origin (5.3\% of the total sample for survey periods 1992, 2000, 2006, 2012; data on place of origin was not available for survey period 1996). Results suggested that inclusion or exclusion of these respondents only marginally affected interpretation of class sizes over time and region (mean difference between class sizes obtained with full sample and class sizes obtained after excluding respondents: $M=0.28 \%, S D=0.36 \%$, $\min =0 \%, \max =1.64 \%$ ) and the association between class membership, time and sociodemographic characteristics (only one observed change in significance, but not direction of covariates: gender in Eastern German sample, see also Appendix G). Therefore, bias attributable to domestic migration was likely to be negligible. 


\section{Conclusion}

Laws should protect women's health and rights and remove barriers to abortion access [40]. To foster women-centred and rightsbased abortion attitudes in the German population, international guidelines on abortion practice and policies should be implemented and inform the public discourse (e.g. WHO) [45]. Public discussions should highlight that restricting abortion access is not associated with reductions in abortion rates but instead has detrimental effects on women's health. Existing interventions specifically geared towards improving abortion attitudes among abortion providers, trainers and policy makers could be applied to reduce barriers to abortion access rooted in abortion stigma [55]. In order to mitigate negative effects of abortion stigma (e.g. shame, secrecy, limited/biased availability of information), nondirective, non-judgemental and voluntary abortion counselling should be offered to women before and after an abortion [56]. Research further suggests that abortion stigma is inherently linked to gender-role norms restricting women to their role as caregivers and mothers [12,57]. Changing these gender stereotypes will require concerted action by policy makers, civil rights organizations, educators and the media, e.g. in the form of comprehensive sexuality education, universal access to contraception and policies sanctioning gender-based discrimination [58]. In general, federal states in Germany need to fulfil their legal obligation to ensure access to abortion care for eligible women [59]. This may be achieved by mandating referral in the case of conscientious objection or permitting abortion providers to inform about all aspects of abortion care [51]. Comprehensive data on abortion service availability is needed in order to understand inequities in abortion access. Future research should aim at understanding the mechanisms underlying changing abortion attitudes in the German population as well as the impact on the well-being of women who have abortions and the impact on their pathways to care.

\section{Data availability statement}

All data used in this study is available online (see references), except for data on the number of abortion facilities, which is available on request from the German Federal Statistical Office.

\section{Supplemental Files}

- Appendix A. Construction of covariates.

- Appendix B. Description of the modelling process.

- Appendix C. Latent class item-response probabilities and sizes for the 4-class model for West Germany.

- Appendix D. Latent class item-response probabilities per region.

- Appendix E. Latent class sizes (\%, 95\% Cl) for the 3-class overall model per year and region.

- Appendix F. Associations with indicators of barriers to abortion care.

- Appendix G. Sensitivity analysis of effect of domestic migration.

\section{Conflict of Interest}

The authors declare that they have no conflict of interest.

\section{References}

[1] Matsubara S. Abortion, Termination of Pregnancy, or Unterbrechung? A Non-English-native Obstetrician's View on Obstetric English Terminology. Geburtsh Frauenheilk 2018; 78: 1217-1218

[2] Helfferich C, Hrsg. Familienplanung im Lebenslauf von Frauen. Schwerpunkt: Ungewollte Schwangerschaften; eine Studie im Auftrag der BZgA von Cornelia Helfferich, Heike Klindworth, Yvonne Heine, Ines Wlosnewski. Köln: Bundeszentrale für Gesundheitliche Aufklärung (BZgA); 2016

[3] Statistisches Bundesamt (Destatis), Hrsg. Schwangerschaftsabbruchstatistik, 2017. Fachserie 12, Reihe 3. Online: https://www.destatis.de/DE/ Themen/Gesellschaft-Umwelt/Gesundheit/Schwangerschaftsabbrueche/ Publikationen/Downloads-Schwangerschaftsabbrueche/ schwangerschaftsabbrueche-2120300177004.pdf; last access: 23.04.2019

[4] Sedgh G, Singh S, Henshaw SK et al. Legal abortion worldwide in 2008 Levels and recent trends. Int Perspect Sex Reprod Health 2011; 37: 8494

[5] de Zordo S, Mishtal J, Anton L, eds. A fragmented Landscape. Abortion Governance and Protest Logics in Europe. New York, Oxford: Berghahn; 2017

[6] Ganatra B, Gerdts C, Rossier C et al. Global, regional, and subregional classification of abortions by safety, 2010-14: estimates from a Bayesian hierarchical model. Lancet 2017; 390: 2372-2381

[7] Culwell KR, Hurwitz M. Addressing barriers to safe abortion. Int J Gynaecol Obstet 2013; 121 (Suppl. 1): S16-S19

[8] Doran F, Nancarrow S. Barriers and facilitators of access to first-trimester abortion services for women in the developed world: a systematic review. J Fam Plann Reprod Health Care 2015; 41: 170-180

[9] Levels M, Sluiter R, Need A. A review of abortion laws in Western-European countries. A cross-national comparison of legal developments between 1960 and 2010. Health Policy 2014; 118: 95-104

[10] Heino A, Gissler M, Apter D et al. Conscientious objection and induced abortion in Europe. Eur J Contracept Reprod Health Care 2013; 18: 231-233

[11] Strafgesetzbuch Paragraf 218-219

[12] Kumar A, Hessini L, Mitchell EMH. Conceptualising abortion stigma. Cult Health Sex 2009; 11: 625-639

[13] Norris A, Bessett D, Steinberg JR et al. Abortion stigma. A reconceptualization of constituents, causes, and consequences. Womens Health Issues 2011; 21 (3 Suppl.): S49-S54

[14] Link BG, Phelan JC, Hatzenbuehler ML. Stigma as a Fundamental Cause of Health Inequality. In: Major B, Dovidio JF, Link BG, eds. The Oxford Handbook of Stigma, Discrimination, and Health. New York: Oxford University Press; 2018: 53

[15] Coast E, Norris AH, Moore AM et al. Trajectories of women's abortion-related care: A conceptual framework. Soc Sci Med 2018; 200: 199-210

[16] Gelman A, Rosenfeld EA, Nikolajski C et al. Abortion Stigma Among LowIncome Women Obtaining Abortions in Western Pennsylvania. A Qualitative Assessment. Perspect Sex Reprod Health 2017; 49: 29-36

[17] Hulme-Chambers A, Clune S, Tomnay J. Medical termination of pregnancy service delivery in the context of decentralization: social and structural influences. Int J Equity Health 2018; 17: 172

[18] Myran DT, Carew CL, Tang J et al. Medical Students' Intentions to Seek Abortion Training and to Provide Abortion Services in Future Practice. J Obstet Gynaecol Can 2015; 37: 236-244 
[19] Banaszak LA. East-West differences in German abortion opinion. Public Opinion Quarterly 1998; 62: 545-582

[20] Stöbel-Richter Y, Brähler E. Einstellungen zur Vereinbarkeit von Familie und weiblicher Berufstätigkeit und Schwangerschaftsabbruch in den alten und neuen Bundesländern im Vergleich. Geburtsh Frauenheilk 2005; 65: 256-265

[21] Wittenberg R. Schwangerschaftsabbrüche - Einstellungen und Hintergründe. Präv Gesundheitsf 2006; 1: 128-139

[22] Simon A. A Right to Life for the Unborn? The Current Debate on Abortion in Germany and Norbert Hoerster's Legal-Philosophical Justification for the Right to Life. J Med Philos 2000; 25: 220-239

[23] Hans JD, Kimberly C. Abortion attitudes in context. A multidimensional vignette approach. Soc Sci Res 2014; 48: 145-156

[24] GESIS - Leibniz-Institut für Sozialwissenschaften. Allgemeine Bevölkerungsumfrage der Sozialwissenschaften ALLBUS - Kumulation 19802014. ZA4582 Datenfile Version 1.1.0. Köln: GESIS Datenarchiv; 2016. doi: $10.4232 / 1.12646$

[25] GESIS - Leibniz-Institut für Sozialwissenschaften. ALLBUS 1980-2014 Allgemeine Bevölkerungsumfrage der Sozialwissenschaften. Variable Report. Köln: GESIS Datenarchiv; 2016

[26] Jelen TG, Wilcox C. Causes and Consequences of Public Attitudes toward Abortion. A Review and Research Agenda. Polit Res Q 2003; 56: 489

[27] Klose J, Rehbein I. Ärzteatlas. Daten zur Versorgungsdichte von Vertragsärzten. Berlin: Wissenschaftliches Institut der AOK; 2017

[28] Klose J, Rehbein I. Ärzteatlas 2011. Daten zur Versorgungsdichte von Vertragsärzten. Berlin: Wissenschaftliches Institut der AOK; 2011

[29] Statistisches Bundesamt (Destatis). Meldestellen zur Schwangerschaftsabbruchstatistik, 4. Quartal 2018 nach Bundesländern. E-Mail, 2019

[30] Statistisches Bundesamt (Destatis). Bevölkerung: Bundesländer, Stichtag, Geschlecht, Altersjahre per 31.12.2017, 2019. Online: https:// www-genesis.destatis.de/genesis/online/link/tabellen/12411*; last access: 04.04.2019

[31] McCutcheon AL. Multiple Group Association Models with Latent Variables. An Analysis of Secular Trends in Abortion Attitudes, 1972-1988. Sociol Methodol 1996; 26: 79

[32] Collins LM, Lanza ST. Latent Class and Latent Transition Analysis: With Applications in the Social, Behavioral and Health Sciences. New Jersey: John Wiley 2010

[33] Schafer JL, Kang J. LCCA package for R users' guide (Version 1.1.0). University Park: The Methodology Center, Penn State. 2013. Online: methodology.psu.edu; last access: 01.03.2019

[34] Nylund KL, Asparouhov T, Muthén BO. Deciding on the Number of Classes in Latent Class Analysis and Growth Mixture Modeling: A Monte Carlo Simulation Study. Struct Equ Modeling 2007; 14: 535-569

[35] Asparouhov T, Muthén B. Auxiliary Variables in Mixture Modeling: ThreeStep Approaches Using Mplus. Struct Equ Modeling 2014; 21: 329-341

[36] Graham JW. Missing data analysis. Making it work in the real world. Annu Rev Psychol 2009; 60: 549-576

[37] Honaker J, King G, Blackwell M. Amelia II. A program for missing data. Stat Softw 2011; 45: 1-47

[38] Reitz D, Richter G. Current changes in German Abortion Law. Camb Q Healthc Ethics 2010; 19: 334-343

[39] Sedgh G, Bearak J, Singh S et al. Abortion incidence between 1990 and 2014. Global, regional, and subregional levels and trends. Lancet 2016; 388: $258-267$

[40] Berer M. Abortion Law and Policy Around the World. In Search of Decriminalization. Health Hum Rights 2017; 19: 13-27

[41] World Health Organization. European Health Information Gateway. Abortions per 1000 live births. Online: https:/gateway.euro.who.int/ en/indicators/hfa_586-7010-abortions-per-1000-live-births/ visualizations/\#id=19681\&tab = notes; last access: 10.07 .2019
[42] Grimes DA, Benson J, Singh S et al. Unsafe abortion. The preventable pandemic. Lancet 2006; 368: 1908-1919

[43] Foster DG, Biggs MA, Ralph L et al. Socioeconomic Outcomes of Women Who Receive and Women Who Are Denied Wanted Abortions in the United States. Am J Public Health 2018; 108: 407-413

[44] Center for Reproductive Rights. Fachliche Stellungnahme des Center for Reproductive Rights zur Vorlage beim Bundestag der Bundesrepublik Deutschland zum Entwurf der Bundesregierung für ein Gesetz zur Verbesserung der Information über einen Schwangerschaftsabbruch (Drucksache 19/7693). Legal and policy considerations Geneva, 2015. Online: https://www.profamilia.de/fileadmin/profamilia/verband/CRR_ expert_opinion_abortion_Print_19-7693_2019_DE.pdf; last access: 28.06.2019

[45] World Health Organization. Safe abortion: technical and policy guidance for health systems: 2nd ed. Geneva: World Health Organization; 2012

[46] Finer LB, Frohwirth LF, Dauphinee LA et al. Reasons U.S. women have abortions. Quantitative and qualitative perspectives. Perspect Sex Reprod Health 2005; 37: 110-118

[47] Loll D, Hall KS. Differences in abortion attitudes by policy context and between men and women in the World Values Survey. Women Health 2019; 59: 465-480

[48] Bock von Wülfingen B. Contested change: how Germany came to allow PGD. Reprod Biomed Soc Online 2016; 3: 60-67

[49] de Zordo S. From women's 'irresponsibility' to foetal 'patienthood'. Obstetricians-gynaecologists' perspectives on abortion and its stigmatisation in Italy and Cataluña. Glob Public Health 2018; 13: 711-723

[50] Hashiloni-Dolev Y, Weiner N. New reproductive technologies, genetic counselling and the standing of the fetus. Views from Germany and Israel. Sociol Health IIIn 2008; 30: 1055-1069

[51] Isenson N. Germany's medical system sidelines abortion, 2018. Online: https://www.dw.com/en/germanys-medical-system-sidelines-abortion/ a-43702057; last access: 10.04.2019

[52] Kulozik D, Wandt L, Svehla A; rbb. Immer weniger Abtreibungsärzte. Bundesärztekammer fordert Hilfe, 2018. Online: https://www. tagesschau.de/inland/kontraste-abtreibung-103.html; last access: 10.04.2019

[53] Seyler H. Schwangerschaftsabbrüche. Internationale Leitlinien, 2014. Online: https://www.profamilia.de/fileadmin/dateien/fachpersonal/ familienplanungsrundbrief/profa_medizin-2014-141021-WEB-ISSN-OK. pdf; last access: 10.07.2019

[54] Hanschmidt F, Linde K, Hilbert A et al. Abortion Stigma. A Systematic Review. Perspect Sex Reprod Health 2016; 48: 169-177

[55] Turner KL, Pearson E, George A et al. Values clarification workshops to improve abortion knowledge, attitudes and intentions. A pre-post assessment in 12 countries. Reprod Health 2018; 15: 40

[56] Hanschmidt F, Hoffmann R, Klingner J et al. Help-seeking Following Termination of Pregnancy after Diagnosis of Fetal Anomaly. Women's Intentions and Experiences 1 to 7 Years after the Event. Geburtsh Frauenheilk 2018; 78: 160-166

[57] Huang Y, Davies PG, Sibley CG et al. Benevolent Sexism, Attitudes Toward Motherhood, and Reproductive Rights. A Multi-Study Longitudinal Examination of Abortion Attitudes. Pers Soc Psychol Bull 2016; 42: 970 984

[58] Starrs AM, Ezeh AC, Barker G et al. Accelerate progress-sexual and reproductive health and rights for all. Report of the Guttmacher-Lancet Commission. Lancet 2018; 391: 2642-2692

[59] Gesetz zur Vermeidung und Bewältigung von Schwangerschaftskonflikten (Schwangerschaftskonfliktgesetz - SchKG). Online: https://www. gesetze-im-internet.de/beratungsg/BJNR113980992.html; last access: 28.06.2019 